\title{
Z) Research Square \\ Healing Features of Experimental Injuries of Soft Tissues That Contain Foreign Bodies In The Form of Fragments Of Military Personnel Uniforms
}

\section{Sergey Pavlov}

Kharkivska Medichna Akademia Pisliadiplomnoy Osviti

\section{Olga Litvinova}

Kharkivska Medichna Akademia Pisliadiplomnoy Osviti

\section{Rostislav Mikhaylusov}

Kharkivska Medichna Akademia Pisliadiplomnoy Osviti

\section{Vladimir Negoduyko}

Vijs'kovo-medichnij klinichnij tsentr Pivnichnogo regionu Ministerstva oboroni Ukraini

Marina Kumetchko ( $\nabla$ cndl@med.edu.ua )

Kharkivska Medichna Akademia Pisliadiplomnoy Osviti https://orcid.org/0000-0002-9153-2461

\section{Nataliia Semko}

Kharkivska Medichna Akademia Pisliadiplomnoy Osviti

\section{Research}

Keywords: Combat trauma, chronic wound, foreign body, textile foreign body, basic fibroblast growth factor, vascular endothelial growth factor

Posted Date: July 6th, 2020

DOl: https://doi.org/10.21203/rs.3.rs-39308/v1

License: (c) (1) This work is licensed under a Creative Commons Attribution 4.0 International License.

Read Full License

Version of Record: A version of this preprint was published at BMJ Military Health on February 5th, 2021. See the published version at https://doi.org/10.1136/bmjmilitary-2020-001666. 


\section{Abstract}

\section{Background}

The healing of combat wounds can be complicated by the presence of foreign bodies (FBs) in the form of fragments of military uniforms in the wound canal. During the experiment, the structural features of the regeneration of soft tissue injuries complicated by FBs in the form of fragments of two types of military uniforms were studied. Changes in the content of the basic fibroblast growth factor (bFGF) and vascular endothelial growth factor (VEGF) during wound healing were studied.

\section{Methods}

By randomization, 60 rats were divided into 4 groups: intact (Int), control (Con) and two experimental (EG1, EG2). A layered incision of the thigh soft tissues was performed on the animals. In Con, wounds were sutured without implantation of FBs. A camouflage uniform consisting of $100 \%$ cotton was used as FBs for EG1, a uniform consisting of $65 \%$ cotton and $35 \%$ polyester was used for EG2. The size of the implanted fragments was $0.5 \times 0.5 \mathrm{~cm}$. The removal of laboratory animals from the experiment was carried out in 6 of each group on the 15th, 30th, 60th day. Histological studies of soft tissue samples were performed according to generally accepted methods. The growth factors content in serum was determined by enzyme-linked immunosorbent assay with the usage of bFGF (Elabscience) and VEGF (Vector-Best) kits.

\section{Results}

In EG1, the inflammatory reaction proceeded intensively and protractedly, which complicated the development and maturation of granulation tissue (GT). In EG2, considering the moderate inflammatory reactions, healing of the wound defect and optimal encapsulation of FB became possible. The increase of the growth factors content in the blood of Con group animals was maximal for a period of 15 days: bFGF -2.2 times, VEGF -1.6 times ( $p<0.001$ compared to Int). In groups of animals with textile implants, the bFGF content was maximal on the 60th day and exceeded the normal values by 1.7 times in EG1and by 2.6 times in EG2 ( $p<0.001$ compared to Int). The level of VEGF in EG1 and EG2 at all stages was slightly higher than in healthy animals.

\section{Conclusion}

At all stages of the experiment, the repair of damaged tissue in rats was complicated by the presence of the textile foreign body (TFB). This confirms the need for thorough debridement of combat wounds during primary surgical treatment. The increase in bFGF production contributed to the development and maturation of GT in the injury area and optimal encapsulation of FBs. The level of VEGF in the experimental groups was increased relative to normal values, which reflected the chronicity of the injuries regeneration process. 


\section{Background}

An increase in the society criminalization, an increase in the number of hunting, sports, traumatic, improvised and illegal firearms in the hands of the population, as well as social, political, territorial and religious conflicts and confrontations lead to an increase in the number of gunshot wounds. The treatment of gunshot wounds is of particular relevance during wars, local military conflicts, anti-terrorist operations, peacekeeping missions and in the post-war period [1]. Among gunshot wounds, a significant number are soft tissue wounds; according to various sources the number varies from 55 to $77 \%$ [2-5]. One of the factors that have a negative effect on the combat wounds healing is the presence of $F B$, which get there with the direct penetrative action of a wounding projectile and a vortex flow generated when the projectile passes through the tissues, in the wound canal. FB contribute to additional trauma and infection of soft tissues, and with prolonged exposure to the body create a focus of chronic inflammation of varying intensity $[6,7]$. Among the FBs that are extracted during primary surgical treatment of wounds, the remains of military uniforms are often found in the form of threads and textiles fragments [8]. However, these kinds of objects often cannot be easily detected or removed.

A wound defect healing (including the one of a gunshot origin), restoration of the anatomical and functional usefulness of damaged soft tissues occur due to GT. In this case, activation of fibroblasts and angiogenesis is important. The regulation of the process of GT development and transformation is ensured by local cellular, tissue, and general factors. One of the main regulators of the GT formation and growth are bFGF and VEGF. bFGF is a mitogen, a factor of differentiation and phenotypic transformation of various types of cells, including fibroblasts and endothelial cells. bFGF activates angiogenesis, stimulates chemotaxis of fibroblasts and their synthetic function for the synthesis of extracellular matrix proteins - collagen and fibronectin [9]. VEGF is one of the most important and powerful growth factors that stimulate angiogenesis. It acts as a mitogen of endothelial cells, a chemotactic agent and an inducer of vascular permeability [10]. In any chronic wound, intercellular and cell-matrix interactions, as well as the dynamics of the content of bFGF and VEGF growth factors during the healing of soft tissue injuries, change. However, the role of these regulatory mechanisms in the healing of wounds containing FB in the form of textile fragments of various compositions remains unexplored.

\section{Materials And Methods}

\section{Objective}

To study changes in the content of bFGF and VEGF growth factors during the regeneration of soft tissue injuries complicated by FB in the form of military uniforms fragments. To identify the features of the healing process regulation by these growth factors. To study the effect of the TFB composition in a wound on its healing progress.

\section{Experimental Animals}


This study was performed on 54 male Wistar rats aged 5 months and weighing $240 \pm 30$ grams. Laboratory animals were kept in the vivarium of the Kharkov Medical Academy of Postgraduate Education. The conditions of detention complied with international regulations (Guidelines for the Care and Use of Laboratory Animals) [11] and included a natural light regime, a standard diet, free access to water and food. Experimental work was carried out in accordance with international requirements for the treatment of animal $[12,13]$.

\section{Study Design}

By randomization, the rats were divided into 4 groups. The Int group for determination of the normal bFGF and VEGF content had 6 healthy rats. Injury modeling was carried out in 3 groups of 18 animals each. The animals underwent a layered soft tissue incision of the right thigh posterior surface $1.0 \mathrm{~cm}$ long with a surgical scalpel No. 11 with a partial section of the muscles. In the Con group, wounds were sutured without FB implantation. EG1 animals were implanted with uniforms fragments of $100 \%$ cotton. Uniforms fragments consisting of $65 \%$ cotton and $35 \%$ polyester were implanted into EG2 animals. The size of the implanted fragments was $0.5 \times 0.5 \mathrm{~cm}$. The implantation of textiles in rats was carried out without injury to the bone and vascular structures, followed by the wound suturing. The removal of laboratory animals from the experiment was carried out in 6 of each group on the 15th, 30th, 60th day after wounds modeling. All surgical operations were performed in a sterile environment in compliance with the rules of asepsis and antiseptics.

\section{Histological Analysis}

For histological examination, soft tissue samples were taken in the area of injury. The material was embedded in paraffin, stained with hematoxylin and eosin, with picrofuksin according to Van Gieson according to the standard methods. The preparations were analyzed and photographed with a PrimoStar microscope (Zeiss) and a Microocular digital camera.

\section{Determination Of The Growth Factors Content}

Blood for research was taken from the heart. The cytokines content in serum was determined by enzymelinked immunosorbent assay using bFGF (Elabscience) and VEGF (Vector-Best) kits.

\section{Statistical analysis}

Statistical processing of the results was performed using Statistica 6.0 statistical analysis package. To describe the results obtained, the data were presented as $M \pm S E$, where $M$ is the arithmetic mean, $S E$ is the standard error of the arithmetic mean. The significance of differences between groups (statistical 
significance) was determined using the non-parametric Kruskal-Wallis ANOVA test for independent samples. Differences were considered statistically significant at $p<0.05$.

\section{Results}

\section{Histological findings}

Histological examination of soft tissue samples in 15 days showed the following results. In animals of all groups, the wounds were completely epithelized. In Con group rats, predominantly maturing GT with moderate leukocyte and macrophage infiltration was observed in wound canals. In areas of extensive injury to muscle tissue, sprouting of connective tissue with a large number of fibroblasts with large, brightly colored nuclei was noted. In EG1 and EG2, wound channels were filled with a maturing GT with focal and diffuse inflammatory infiltration, with a large number of macrophages and foreign body giant cells (FBGCs). Around the textile implants, two-layer connective tissue capsules were formed. In EG1, both capsule layers consisted mainly of immature GT with pronounced leukocyte, macrophage, FBGCs infiltration, with hemorrhages in the capsule walls thickness. In EG2, the capsules were thinner. Both layers consisted of a maturing GT. Leukocyte infiltration of the capsule walls was weak in the outer layer and moderate with macrophages and FBGCs in the inner layer.

After 1 month, the maturation of GT continued in the zone of soft tissue damage in Con group animals. This was reflected in a decrease in the number and differentiation of blood vessels, fibrocytes numerical predominance over fibroblasts, thickening and order of collagen fibers bundles. In histological preparations EG1, pronounced signs of inflammation and edema were noted both in FB capsules and in the surrounding tissues. The outer layer of the capsule consisted of maturing connective tissue with large vessels, the inner layer consisted of immature GT. At the same time, a moderate inflammatory response was observed in EG2 in the capsule walls and surrounding tissues. The outer layer of the capsule was formed by mature connective tissue with tightly packed bundles of collagen fibers and differentiated vessels. In the inner layer, the arrangement of collagen fibers was predominantly chaotic; a moderate number of capillary type vessels was noted. Around the implant textile fibers, proliferation of fibroblasts and the formation of collagen fibers were observed.

After 2 months, there were scars of dense connective tissue in the Con group animals subcutaneous tissue and muscles. Pronounced inflammation persisted in EG1, especially in the inner layer of the capsule. A small number of implant fibers was integrated into the immature GT. In EG2, inflammation in the FB area was mild. Intensive sprouting of connective tissue between the textile fibers inside the capsule consisting of mature connective tissue was observed (Fig. 1).

\section{The Bfgf And Vegf Content}

The dynamics of changes in the growth factors content in animal groups was multidirectional. The increase of the growth factors content in the blood of Con group animals was maximal for a period of 15 
days: bFGF - by 2.2 times, VEGF - by 1.6 times ( $p<0.05$ compared to Int). Then their production decreased and at the end of the experiment did not significantly differ from the values of Int group animals. In EG1 and EG2, the content of bFGF increased over time. On the 60th day, it exceeded the normal values in EG1 - by 1.7 times and in EG2 - by 2.6 times ( $p<0.05$ compared to Int). The level of VEGF in EG1 and EG2 at all periods was slightly higher than in healthy animals (Fig. 2).

\section{Discussion}

A significant increase in the growth factors content in Con group over a period of 15 days compared to Int is associated with the actively proliferating phase in the healing process of these deep wounds. In studies on the skin wounds healing, an increase in the growth factors content was also established: bFGF - on days 10 and 21, VEGF - on days 3 and 10 [14]. With a decrease in the expression of pro-inflammatory cytokines by various methods, an increase in the growth factors release was noted [14, 15]. In our study, lower levels of growth factors in animals EG1 and EG2 compared to Con were likely to be associated with inflammatory responses of rats' bodies to FB in soft tissues. At the microscopic level, this was reflected in pronounced leukocyte and macrophage infiltration of GT, FB capsule and surrounding tissues.

After 1 month, signs of the reparative processes transition into the remodeling phase were observed in the Con group. A significant decrease in the growth factors bFGF and VEGF content in the blood serum was noted. As a result, in the area of injury, there was a decrease in the number of capillaries and fibroblasts, an increase in the diameter of the bundles of collagen fibers. It is believed that apoptosis of cells and arrest of capillary growth occur due to changes in the growth factors release $[16,17]$. At the same time, there were slight changes in the growth factors content in EG1, and pronounced inflammatory and destructive phenomena were present in the $\mathrm{GT}$ in the $\mathrm{FB}$ region. In EG2, considering a significant increase in bFGF and relatively stable VEGF, moderate inflammation, as well as the formation and maturation of GT, were noted.

By the end of the experiment, the repair of injured soft tissues in Con group was completed, and the growth factors content in the blood serum was close to normal values. In EG1 and EG2, at similar values of VEGF levels, both the content of bFGF and the histoarchitectonics of soft tissues in the FB region sharply differed. In EG1, with a slight increase in the level of bFGF, pronounced inflammation in the FB capsule and in the surrounding tissues remained, which impeded the normal development and maturation of GT. It is known that a prolonged increase in the level of pro-inflammatory cytokines and proteases in the area of injury prevents the normal progression of wound healing [18]. In EG2, in contrast, the bFGF content was the highest, which led to the intensive development of connective tissue between the encapsulated TFB fibers. By the end of the experiment, the implants in EG2 were isolated from the surrounding tissues and "immobilized" with dense connective tissue membranes and interlayers inside the capsule. This structural organization is characteristic for various kinds of FB and contributes to their stabilization in the soft tissues of the body [19-21]. Thus, the possibilities of contacts with the internal environment of the body and their migration into the surrounding tissues for FB are significantly limited. 
The consequences of this can be trauma, new foci of inflammation and, as a result, the appearance of new granulations and sclerotic tissues.

The differences in the wound repair processes between EG1 and EG2 are probably due to the physicochemical properties of textile fibers. As it is known from surgical practice, natural suture material (silk, cotton) has pronounced sorption abilities, which causes aseptic inflammation up to the formation of necrosis. Threads made on the basis of synthetic compounds, in contrast, are more inert and give a minimal cellular response [22]. The surface properties of implantable materials can determine the further wounds healing by interacting with macrophages [23]. When acute damage is restored, two subtypes of macrophages are distinguished [24]. Macrophages of the first subtype dominate the area of injury during the first 3 days and secrete inflammatory mediators, carry out proteolysis and phagocytosis. After 4-7 days, macrophages of the second subtype, which express anti-inflammatory cytokines and growth factors, accumulate. The macrophages adhered to the surface of various implants can combine the signs of two subtypes [23]. They are considered the main mediators of the FB reaction and can affect the behavior of other leukocytes, fibroblasts, keratinocytes through the secretion of cytokines.

The prolonged and pronounced inflammation observed in EG1 in the FB region indicates that the structure, physical and chemical properties of the fibers of military uniforms fragments of $100 \%$ cotton made wound healing difficult. The cellular response to the material persisted after two months after implantation. Due to the prolonged phase of inflammation and the low content of bFGF in the blood serum of animals, the proliferative phase in wound regeneration was mild. As it is known, the proliferative activity of tissues in the area of injury largely determines the speed of wound healing [25]. In EG2 with implanted fragments of a uniform textile consisting of $65 \%$ cotton and $35 \%$ polyester, inflammatory reactions were less pronounced. The biological inertness of these textile fibers, which include a significant number of synthetic threads, was a possible reason. This created less obstacles to the GT development. Considering a high level of bFGF in EG2, maturation and structural organization of connective tissue in the foreign body region became possible.

The VEGF content in Con group was maximal for 15 days, and then decreased to normal values. This is confirmed by the literature on the increased release of VEGF in the early stages of normal wound healing $[14,26]$. The level of VEGF in EG1 and EG2 at all periods did not show significant differences and was slightly higher than normal values. Perhaps the increase in VEGF production was the result of chronic hypoxia, which is inherent in chronic wounds [27]. It has also been shown that in chronic wounds, inflammatory and oxidative signaling induces VEGF expression [28]. In addition, VEGF itself plays an important role in initiating inflammation by attracting macrophages and mast cells into the wound and/or activating them [29].

The results of the experiment confirm the need for thorough debridement of combat wounds during primary surgical treatment. FB in the form of fragments of military personnel uniforms violate the normal wound healing process. From acute damage, the wound becomes chronic. Changes in the mechanisms of intercellular interactions, which are also regulated by growth factors, lead to violations of the structural 
organization in the damage zone. Pathological processes in the soft tissues continued at remote periods without visible manifestations on the skin surface.

Changes in the growth factors content during the regeneration of soft tissue injuries complicated by TFB make it possible to identify the following features. bFGF production increased with an inflammation decrease in the injury area. The level of bFGF was a determining factor in the process of formation and organization of connective tissue regulating in the FB region. The content of VEGF did not depend on the severity of the inflammation process. Its increased production in injuries complicated by foreign bodies, apparently, is a link in the reaction chain of the chronic wounds healing pathological process. Further studies are needed to clarify the role of VEGF in the regeneration of such injuries. The determination of these growth factors content in the blood may prospectively be a prognostic indicator of the combat trauma healing.

\section{Conclusion}

Our study showed that at all stages of the experiment, the repair of damaged tissue in rats was complicated by the presence of the textile implant. This confirms the need for thorough debridement of combat wounds during primary surgical treatment. In EG1 with implanted fragments of military uniforms consisting of $100 \%$ cotton, the inflammatory reaction proceeded more intensively and for a long time. At the same time, bFGF production was reduced, which complicated the GT development and maturation. In EG2 with implanted pieces of military uniforms consisting of $65 \%$ cotton and $35 \%$ polyester, inflammatory reactions were less pronounced. Moreover, a gradual increase in bFGF production contributed to the development and maturation of GT in the injury area, as well as optimal encapsulation of FB. The level of VEGF in EG1 and EG2 was increased relative to normal values, reflecting the chronicity of the wound regeneration process.

\section{Abbreviations}

bFGF

basic fibroblast growth factor

Con

control group

EG1

experimental group 1

\section{Declarations}

\section{Ethics approval and consent to participate}

Permission of the Local Ethical Commission of the Military Medical Clinical Center of the Northern Region of the Ministry of Defense of Ukraine No. 2/10 dated 10.19.2018 was obtained for the study. 


\section{Consent for publication}

Not applicable.

\section{Availability of data and materials}

The datasets during and/or analyzed during the current study are available from the corresponding author on reasonable request.

\section{Competing interests}

The authors declare that they have no competing interests.

\section{Funding}

This study was funded by the Ministry of Health of Ukraine for the state budget.

\section{Authors' contributions}

SP designed this study and made revisions throughout the article. OL performed the histological examination of the soft tissues, and was a major contributor in writing the manuscript. MK contributed to the statistical analysis of the data. The remaining authors significantly contributed to the animal experiments. All authors contributed to and approved the final manuscript.

\section{Acknowledgements}

Not applicable.

\section{Authors' information}

Sergey Pavlov

PhD, DSc in Biology. Central Research Laboratory, Kharkiv Medical Academy of Postgraduate Education, 58 Amosova st., Kharkiv, 61176, Ukraine.

Olga Litvinova

Central Research Laboratory, Kharkiv Medical Academy of Postgraduate Education, 58 Amosova st., Kharkiv, 61176, Ukraine

Rostislav Mikhaylusov

PhD, DSc in Medicine. Department of Endoscopy and Surgery, Kharkiv Medical Academy of Postgraduate Education, 58 Amosova st., Kharkiv, 61176, Ukraine.

Vladimir Negoduyko 
PhD, DSc in Medicine. Emergency clinic, Military Medical Clinical Center of the Northern Region of the Ministry of Defense of Ukraine, 5 Kultury st., Kharkiv, 61058, Ukraine.

Marina Kumetchko

Central Research Laboratory, Kharkiv Medical Academy of Postgraduate Education, 58 Amosova st., Kharkiv, 61176, Ukraine.

Nataliia Semko

Central Research Laboratory, Kharkiv Medical Academy of Postgraduate Education, 58 Amosova st., Kharkiv, 61176, Ukraine.

\section{Footnotes}

Not applicable.

\section{References}

1. Harbrecht BG, Miller KR, Motameni AT, Benns MV, Bozeman MC, Nash NA, Franklin GA, Smith JW. Gunshot Injuries to the Extremity: Is Immediate General Surgery Presence Needed? Am Surg. 2018;84(9):1450-4.

2. Shudrak AA. Boyova khirurgichna travma v khodi provedennya ATO. 2015. http://www.isurgery.com.ua/uploads/presentations/shurdak.pdf. Accessed 25 Feb 2015. [Document in Ukrainian].

3. Djenić $N$, Višnjić M, Dragović S, Bojanić V, Bojanić Z, Djurdjević D, et al. Experimental closure of gunshot wounds by fibrin glue with antibiotics in pigs. Vojnosanit Pregl. 2015;72(9):785-93.

4. Gregory TM, Bihel T, Guigui P, Pierrart J, Bouyer B, Magrino B, et al. Terrorist attacks in Paris: Surgical trauma experience in a referral center. Injury. 2016;47(10):2122-6.

5. Abghari M, Monroy A, Schubl S, Davidovitch R, Egol K. Outcomes Following Low-Energy Civilian Gunshot Wound Trauma to the Lower Extremities: Results of a Standard Protocol at an Urban Trauma Center. lowa Orthop J. 2015;35:65-9.

6. Connolly M, Ibrahim ZR, Johnson $\mathrm{ON}$. Changing paradigms in lower extremity reconstruction in warrelated injuries. Military Med Res. 2016. doi:10.1186/s40779-016-0080-7.

7. Gumanenko EK, et al. Voyenno-polevaya khirurgia: textbook. 2nd ed. Moscow: GEOTAR-Media; 2016. [Book in Russian].

8. Negoduyko V, Mikhaylusov R, Velikodnyi A, Kovtun K. Research of foreign bodies soft tissue gunshot origin. Georgian Med News. 2019; (297): 13 - 7. [Article in Russian].

9. Akita S, Akino K, Hirano A. Basic Fibroblast Growth Factor in Scarless Wound Healing. Adv Wound Care (New Rochelle). 2013;2(2):44-9. 
10. Brem H, Kodra A, Golinko MS, Entero H, Stojadinovic O, Wang VM, et al. Mechanism of Sustained Release of Vascular Endothelial Growth Factor in Accelerating Experimental Diabetic Healing. J Invest Dermatol. 2009;129:2275-87.

11. Guide for the care and use of laboratory animals. Committee for the Update of the Guide for the Care and Use of Laboratory Animals; Institute for Laboratory Animal Research; Division on Earth and Life Studies; National Research Council of the national academies. 8th ed. Washington: The National Academies Press; 2011. 246 p.

12. Directive 2010/63/EU of the European parliament and of the Council of 22 September 2010 on the protection of animals used for scientific purposes. EUR-Lex Official Journal. 2019. https://eurlex.europa.eu/legal-content/EN/TXT/PDF/?uri=CELEX:32010L0063\&from=EN. Accessed 26 Jun 2019.

13. European Convention for the Protection of Vertebrate Animals used for Experimental and other Scientific Purposes. ETS No.123, Strasbourg, 18/03/1986. https://www.coe.int/en/web/conventions/full-list/-/conventions/treaty/123.

14. Chen Y, Tian L, Yang F, Tong W, Jia R, Zou Y, et al. Tannic Acid Accelerates Cutaneous Wound Healing in Rats Via Activation of the ERK 1/2 Signaling Pathways. Adv Wound Care (New Rochelle). 2019;8(7):341-54.

15. Yu C, Xu Z, Hao Y, et al. A novel microcurrent dressing for wound healing in a rat skin defect model. Military Med Res. 2019. doi:10.1186/s40779-019-0213-x.

16. Honnegowda TM, Kumar P, Udupa EGP, Kumar S, Kumar U, Rao P. Role of angiogenesis and angiogenic factors in acute and chronic wound healing. Plastic and Aesthetic Research. - 2015; 2: 243-9.

17. Maksimova NV, Lyundup AV, Lubimov RO, Melnichenko GA, Nikolenko VN. Pathophysiological aspects of wound healing in normal and diabetic foot. Vestn Ross Akad Med Nauk. 2014; (11-12): 110-7. [Article in Russian].

18. Guo S, DiPietro LA. Factors Affecting Wound Healing. J Dent Res. 2010;89(3):219-29.

19. Maiborodin IV, Shevela Al, Matveeva VA, Drovosekov MN, Barannik MI, Kuznetsova IV. Morphological tissue changes after the implantation of elastic lamellar foreign bodies in the experiment. Morfologiia. 2012;141(2):54-60. [Article in Russian].

20. Maiborodin IV, Shevela Al, Kuznetsova IV, Barannik MI, Maiborodina VI. Tissue Responses to Silicone Materials in the Body. Arkh Patol. 2013;75(4):28-33. [Article in Russian].

21. Maiborodin IV, Kuznetsova IV, Beregovoy EA, Shevela Al, Barannik MI, Manayev AA, et al. Tissue reactions during the degradation of polylactide implants in the body. Morfologiia. 2013;143(3):5965. [Article in Russian].

22. Fawad Javed M, Al-Askar K, Almas GE, Romanos. Khalid Al-Hezaimi. Tissue Reactions to Various Suture Materials Used in Oral Surgical Interventions. ISRN Dent. 2012. doi:10.5402/2012/762095.

23. Anderson JM, Rodriguez A, Chang DT. Foreign body reaction to biomaterials. Semin Immunol. 2008;20(2):86-100. 
24. Nahrendorf M, Swirski FK, Aikawa E, Stangenberg L, Wurdinger T, Figueiredo J-L, et al. The healing myocardium sequentially mobilizes two monocyte subsets with divergent and complementary functions. J Exp Med. 2007;204(12):3037-47.

25. Veligotskiy AN, Savitskiy RV, Pavlov SB, Leonov AV. Changes in the area of the wound surface on exposure low-dose vacuum. Klin Khir. 2016; (7): 40-2. [Article in Russian].

26. Johnson KE, Wilgus TA. Vascular Endothelial Growth Factor and Angiogenesis in the Regulation of Cutaneous Wound Repair. Adv Wound Care (New Rochelle). 2014;3(10):647-61.

27. Rodriguez PG, Felix FN, Woodley DT, Shim EK. The role of oxygen in wound healing: a review of the literature. Dermatol Surg. 2008;34:1159-69.

28. Bodnár E, Bakondi E, Kovács K, Hegedús C, Lakatos P, Robaszkiewicz A, et al. Redox Profiling Reveals Clear Differences between Molecular Patterns of Wound Fluids from Acute and Chronic Wounds. Oxid Med Cell Longev. 2018. doi:10.1155/2018/5286785.

29. Wilgus TA. Vascular Endothelial Growth Factor and Cutaneous Scarring Adv Wound Care (New Rochelle). 2019; 8(12): 671-8.

\section{Figures}




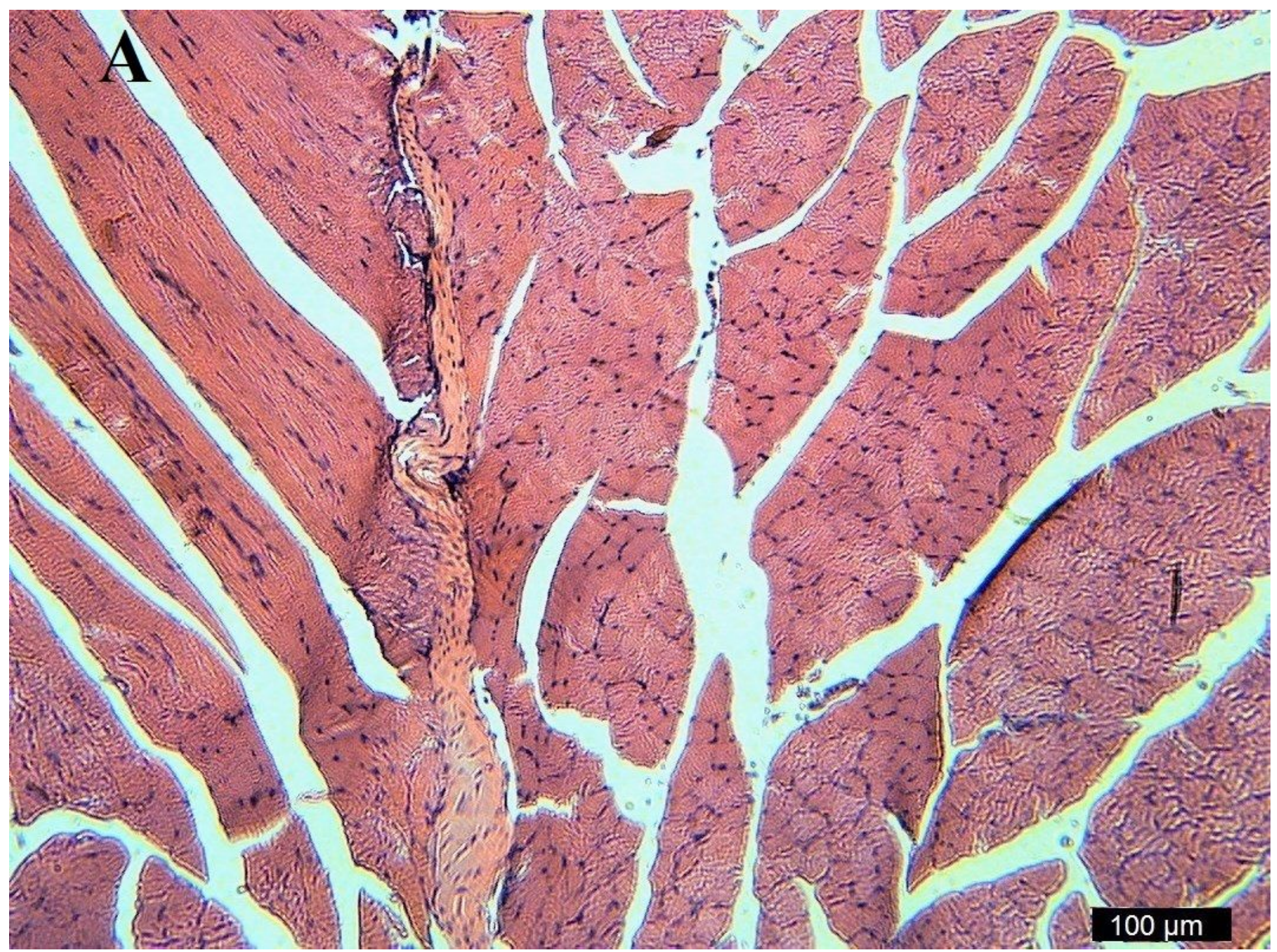

Figure 1

Soft tissue areas from the injury area after 2 months: a) in the control group - scar tissue in the muscles, 


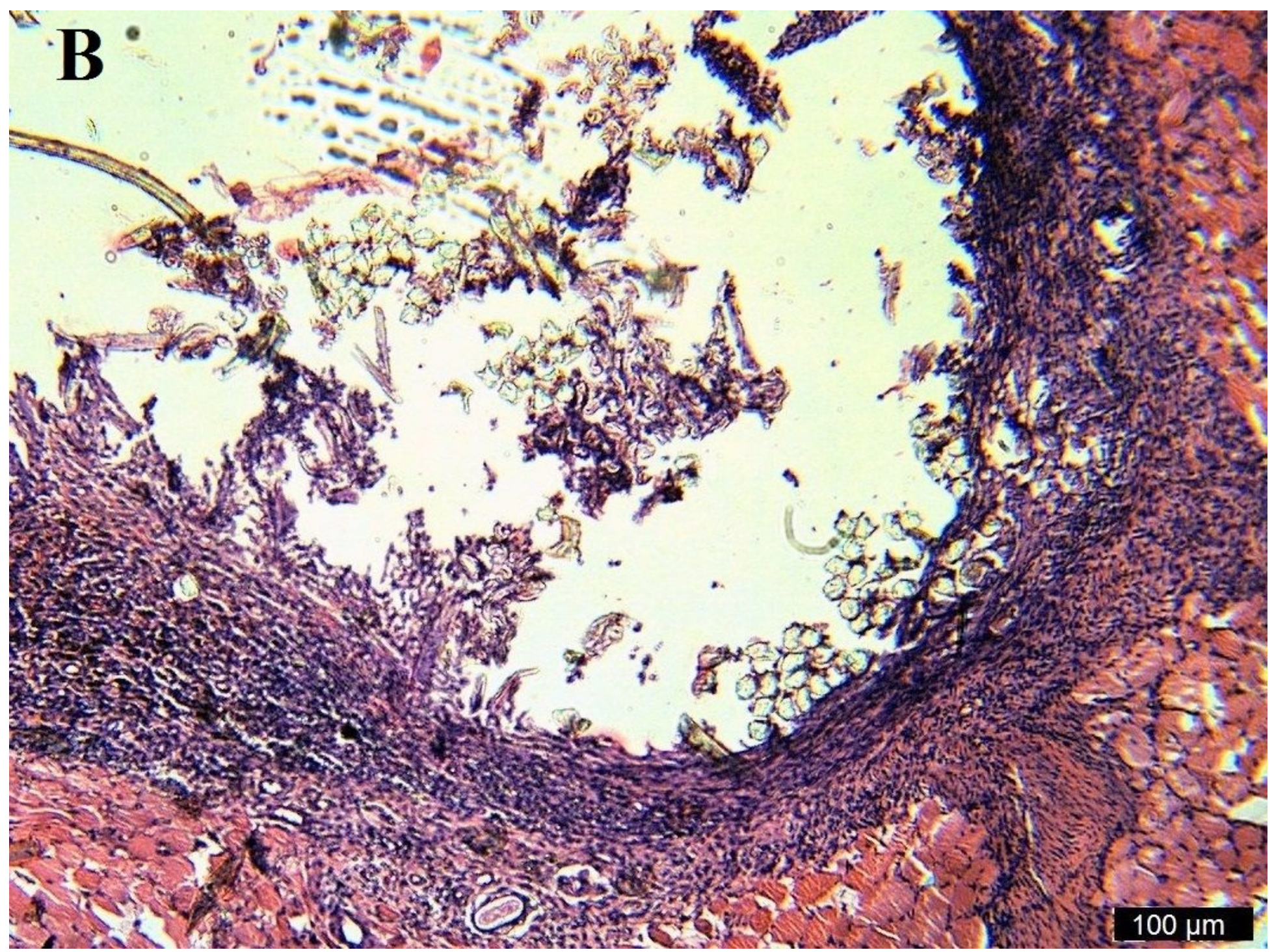

Figure 2

Soft tissue areas from the injury area after 2 months: b) in EG1 - inflammatory infiltration of the capsule wall and surrounding tissues, free implant fibers in the capsule's lumen, 


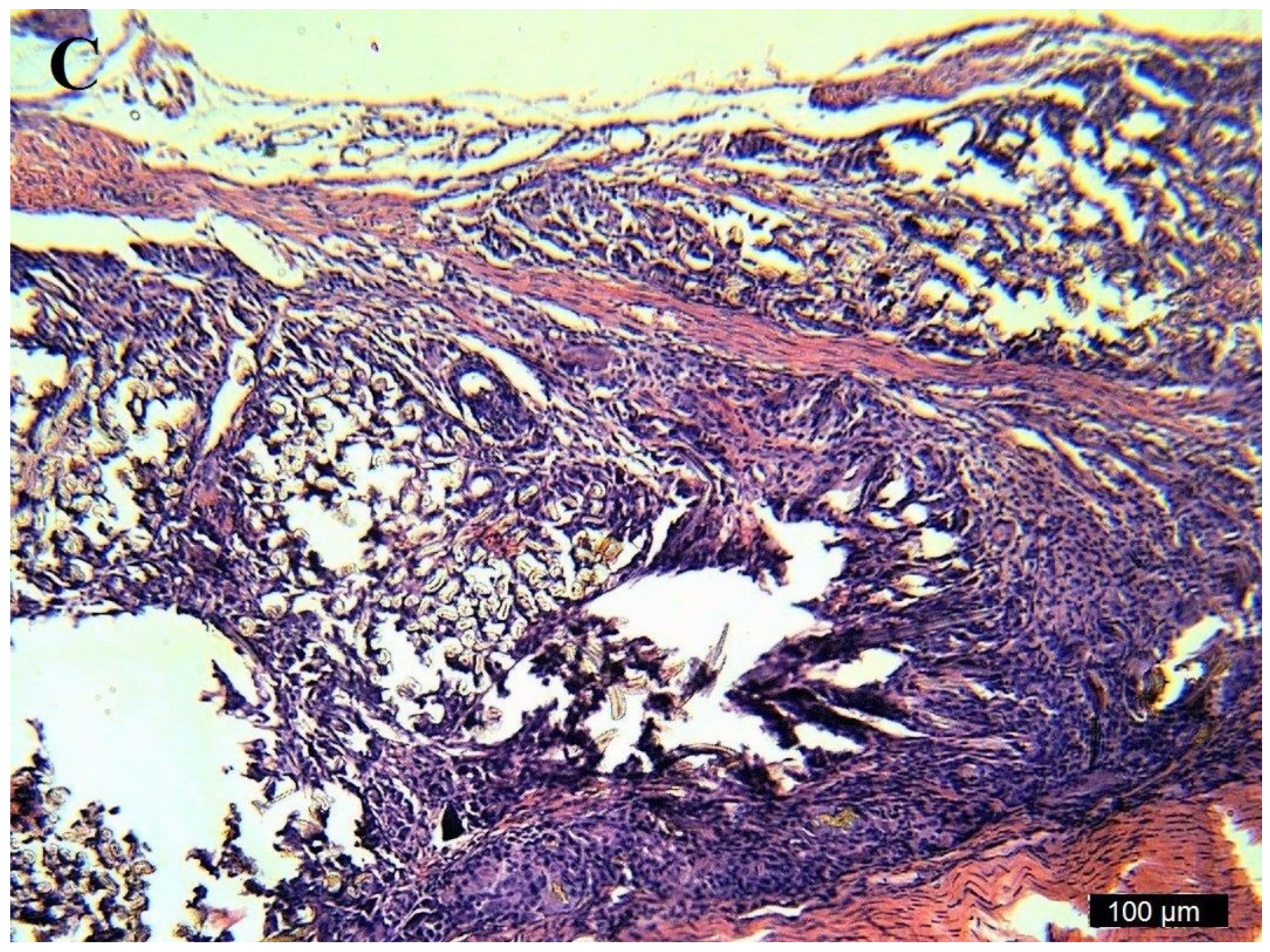

Figure 3

Soft tissue areas from the injury area after 2 months: c) in EG2 - implant fibers inside the capsule are surrounded by young connective tissue. H\&E. Scale bar $100 \mu \mathrm{m}$.
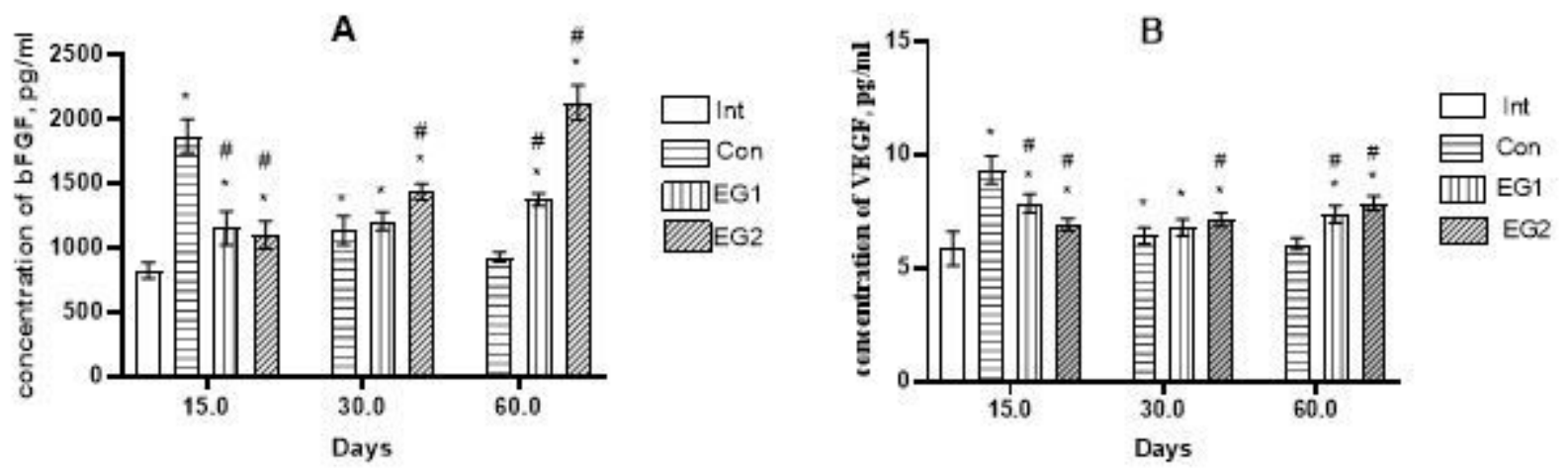

Figure 4 
The growth factors content in the blood serum of animals: A - bFGF, B - VEGF, * $-p<0.05$ compared to Int, \# - $p<0.05$ compared to Con. 